peoples of Africa, in war as much as in peace, need all that science can do to promote their welfare and advancement. "It seems to us important," says Lord Lugard, "that public interest in the welfare of the African peoples should not be 'blacked out' by a too exclusive concentration on events in Europe", adding "we are convinced that the Governments which have accepted responsibilities in Africa will not wish the war to put a stop to the various efforts at the social progress of its peoples, which they have initiated in years of peace." That this view is justified is borne out by the mission undertaken by Lord Hailey at the request of the Colonial Office, to which reference is made above. Further, if the War of 1914-18 may be regarded as a precedent, the problems of native Africa, when peace comes, will not be such as can be solved by improvisation, but only on a basis of the results of carefully digested scientific study over a considerable period.

\section{African Native Institutions and Christianity}

A STRIKING instance of the adaptation of African institutions and ways of thought to the promotion of Christianity after intensive study is contributed to the current issue of Africa (13, 1, January 1940) by Prof. N. de Cleene. Incidentally, it illustrates the flexibility, to which reference is often made, of Catholic Missions in dealing with native races. In response to a suggestion made by Prof. de Cleene that native art might be of service in the Christianization of Africa, the R. P. A. Walschap, a missionary in the Belgian Congo, made a scientific study of native music and the dance. Being struck by the predominating part played in native appreciation by the element of rhythm, not only did he introduce it into his church services, composing a mass and other music in native style, to be sung to the accompaniment of native instruments, but he also arranged a series of religious dances, in the native convention, for performance at the religious festivals of the Church. The result was a remarkable accession of interest and understanding.

The second example makes use of the graphic arts. The R. P. Vandenhoudt, from the time of his arrival on the Lower Congo some years ago, had made a study of the principles, methods and concepts of native graphic art. He was much struck with native ability in making crude but graphic representations of scenes and events in everyday life. He thereupon conceived the idea of representing scenes from the Holy Scriptures according to native concepts and in native technique. Among a number of scenes to which the method was applied, the most successful, and one which was immediately understood, was the sacrifice of Isaac by Abraham, in which the intended victim was represented according to a native custom, in which the head of a man condemned to be beheaded was fastened to the bent bough of a tree and shot into the air when the fatal blow was struck.

\section{The British Museum (Natural History)}

THE important entomological collections, manuscripts, etc., bequeathed by the late William Miller Christy have been received at the Museum. The total number of specimens is 21,312 . The collection consists entirely of British Lepidoptera, and includes a large number of specimens which will be of great value as additions to the existing British collection. Mrs. Brownlow, who inherited them, has presented to the Museum a large number of important entomological books from the library of the late Mr. Christy. Further specimens of vanadinite (lead vanadate), including a doubly terminated crystal from Abenab, South West Africa, have been presented to the Department of Mineralogy by Mr. J. N. Justice, and the Department has also acquired two fine specimens of the rare potassium barium zeolite harmotone collected during the summer of 1939 at Ben Resipol, Argyll.

The Trustees of the British Museum decided at their meeting on January 26 that certain of the galleries in the Natural History Museum should be opened to the public on Saturday and Sunday afternoons, beginning on February 3. Much material has been evacuated for greater safety, and many exhibits have been protected in their places in the galleries. There remains, however, a very large proportion of the exhibits in certain galleries, and the Trustees are anxious that the public should have access to them so far as possible. In addition, it is hoped to organize a number of special exhibits of topical interest, about which a further announcement will be made at a later date. The hours of opening will for the present be from 1 p.m. to 4 p.m. (on Saturdays and Sundays only), but the closing hour will be extended as soon as the lengthening of the days and the introduction of summer time make this practicable. Children below the age of twelve will not be admitted unless they are in the charge of an adult, and visitors are requested to carry gas masks.

\section{The Newcomen Society}

AT a meeting of the Newcomen Society held at the Institute of Marine Engineers on January 17, Eng.-Capt. E. C. Smith read the second part of his paper on "The First Twenty Years of Screw Propulsion 1838-1858". Having in Part 1 dealt with the work of John Ericsson in the United States, Capt. Smith gave a review of the early progress of screw propulsion in both the Royal Navy and the British Mercantile Marine. The first screw vessel in the Royal Navy was the curious little Bee of 33 tons and 10 horse-power built in 1842 and fitted with a side-lever engine driving both paddle-wheels and a screw. The Bee for many years was attached to the Royal Naval College, Portsmouth, for the instruction of officers in steam. The first screw man-of-war in the Navy was the sloop Rattler, the trials with which in 1844-45 led to the screw being adopted for practically all naval vessels. By 1850 there were about forty screw ships in the Fleet, by 1858 and about 350 . Generally speaking, in the larger wooden ships the screw was regarded as an auxiliary and was fitted so that it could be lifted out of the water.

The first mercantile screw vessel to make a sea voyage was the Novelty of 1841. The famous iron screw ship Great Britain was laid down in 1839 and completed 